\title{
Jambi City community transportation modes and influencing factors
}

\author{
Junaidi"; Yulmardi; Hardiani
}

Department of Economics, Faculty of Economics and Business, Universitas Jambi, Indonesia

*To whom correspondence should be addressed.Email: junaidi@unja.ac.id

\begin{tabular}{|l|l|l|l|l|}
\hline DOI: & Received: & Revised: & Accepted: & Published: \\
10.22437/ppd.v8i5.11223 & 29.11 .2020 & 26.12 .2020 & 27.12 .2020 & 31.12 .2020 \\
\hline
\end{tabular}

\begin{abstract}
This study aims to analyze the Jambi City community transportation modes' needs and diversity and influencing factors. This study uses primary data and secondary data. Primary data comes from a sample of households in Jambi City. Meanwhile, secondary data comes from related agencies or institutions at the National, Provincial, and City of Jambi levels related to transportation macro conditions. This study uses descriptive statistical analysis to analyze the diversity of transportation modes used in Jambi City. Meanwhile, to analyze the factors that influence transportation mode choice, it is estimated using logit ordinal regression models. The analysis results found that the primary mode of transportation used by the Jambi City community was personal motorbikes. Public transportation is the second choice, and the use of private cars is the third option. The choice of transportation mode is influenced by gender, main activity, car ownership, motorcycle ownership, and household income.
\end{abstract}

Keywords: Ordinal logit, Transportation modes, Urban

JEL Classsification: O18, R22, R41

\section{INTRODUCTION}

The transportation sector has an important role and relationship with economic growth. Adequate transportation will improve accessibility and the allocation of resources and time (Maryanta, 2005). Especially in urban areas, transportation is vital because the city functions as the center of community activities, both social and economic. A good transportation system will create a city that is efficient, with high growth, and can provide optimal welfare to its people. On the other hand, a city with a poorly organized transportation system will cause chronic congestion, inefficiency, and hamper urban growth.

As the capital city of Jambi Province, Jambi City is one of Indonesia's urban areas that has overgrown in terms of the economy and various other development fields. It has attracted the public's interest in doing activities in this city, both in Jambi Province and people outside Jambi Province. It has an impact on the high level of urbanization in Jambi City. Data for 2019 shows that the population density of Jambi City reaches 2,602 people per $\mathrm{km} 2$, which is far above the average population density of 62 people per $\mathrm{km} 2$ in Jambi Province (BPS, 2020b). 
High urbanization in urban areas will trigger a high level of population density. It shows that the city has functioned as an innovation engine that provides many jobs and social services. On the other hand, the high population density will trigger high demand for population mobility (Böhler-Baedeker et al., 2014; Sekhar, 2014). This fact is also found in Jambi City. The need for transportation in Jambi City has increased rapidly. It can be seen from the increase in traffic volume due to increased vehicles and increased frequency of community trips. During the 2014-2018 period, two-wheeled vehicles in Jambi City reached 23.12 percent per year, and four-wheeled vehicles reached 38.10 percent per year (BPS, 2020a).

On the other hand, during this period, the road's length did not increase, which only grows 0.19 percent per year (BPS, 2019). This condition causes high levels of congestion on the main roads in Jambi City during peak hours. Research by Hardiani, Junaidi, and Achmad (2015) and Amril and Junaidi (2019) found high traffic jams in Jambi City during peak hours, especially on roads leading to housing offices.

Based on this, reducing traffic congestion is one of the main targets that must be carried out in transportation policy in Jambi City. It is necessary considering the economic losses caused by the massive traffic congestion, such as travel delays, wasted fuel consumption, wasted time, and others. Travel delays reduce economic productivity and quality of life.

Jambi City can implement various policies to reduce congestion. However, for the policy to be effective and on target, it requires information and studies on community needs for transportation and the choice of the mode of transportation used. This study aims to analyze the needs and diversity of transportation modes used by the people of Jambi City and the factors that influence the choice of transportation modes for the people of Jambi City.

\section{LITERATURE REVIEW}

\section{Transportation and modes of transportation}

Transportation is a significant component in life and living systems, government systems, and social systems. The transportation system is a fundamental infrastructure element (Amin \& Hasbullah, 2018) that affects urban development patterns (Aminah, 2007). The vital role of the transportation sector for economic activity requires an effective and efficient transportation system. An effective transportation system refers to a transportation system that can meet the transport capacity. It is integrated between modes, orderly, regular, smooth, fast and precise, safe, safe, comfortable, and economically affordable. Efficient transportation will positively impact the public burden as transportation service users become low and have high utility. According to (Dwiatmoko, 2019), these things at the next stage will increase competitiveness, productivity, and innovation that can trigger economic growth.

Transportation is a tool for activities that aim to move, transport, and divert goods and people from their place of origin to their destination to be more useful or can be used for specific purposes (Andriansyah, 2015; Tamin, 2000). There are two essential transportation elements: moving and physically changing goods (commodities) and passengers to other places (Salim, 2016).

Community travel activities in meeting household need better and cheaper have encouraged various tools or modes (Rahmani, 2000). Mode of transportation is a type of transportation infrastructure used to move people and goods from their place of origin to 
their destination, influenced by geographical conditions and technological developments (Azis \& Asrul, 2018). The findings of Alfadin et al. (2018) suggest that the choice of transportation mode is simply related to the type of transportation used. The types of transportation used are usually private vehicles (bicycles, motorbikes, cars) or public vehicles (buses, public transportation, rickshaws, trains, etc.).

\section{Demand and choice of transportation modes}

Demand for transportation services is a demand derived from human needs to carry out activities from one place to another and the need for the availability of goods at the destination place (Andriansyah, 2015). Therefore, the more human activities, and the more human needs, the more demand for transportation services increases. Every individual or household always tries to maximize utility, which is directly faced with the choice of various opportunities they have (Maryanta, 2005). So, to increase effectiveness when traveling, people need to choose the best mode of transportation used.

Travel behavior and the pattern of choosing transportation mode affect traffic congestion (Sugiyanto, 2013). Therefore, an understanding of the factors that influence transportation mode choice can be used as a basis for determining appropriate transportation policies.

According to (Bottai et al., 2006; Cao et al., 2007; Handy et al., 2006; Limtanakool et al., 2006; Setyodhono, 2017), there are two groups of factors that influence transportation demand, which is also aspects of community consideration in choose the mode of transportation. First, it is the socio-economic factors of an individual or household: income level, vehicle ownership, type of work, age, gender, marital status, number of dependent children, number of workers, etc. The second is the travel characteristic factor. In this case, travel characteristics include travel distance, travel purpose, travel time, and travel costs.

\section{Previous research}

Various studies have been carried out regarding the factors that influence transportation modes in cities in Indonesia. Indra and Sukarman (2014) found that travel time and distance affect private and public transportation modes in Palembang City. Riani et al. (2018), in their research regarding the choice of travel mode to shopping centers using private vehicles (motorbikes and cars), found that factors that influence the choice of travel mode are gender, expenditure, motorcycle ownership, trip length, and the relative travel time of the car.

Research on transportation modes has also been carried out in cities in various countries in the world. Sugiyanto (2013), in his research in the Philippines, found that daily travel patterns, trip characteristics, socio-economic characteristics, and transportation policies' effectiveness influenced transportation modes' choice. (Madhuwanthi et al., 2016) in West Sri Lanka Province found that factors that influence the choice of transportation modes are vehicle ownership, safety, and comfort. (Ashalatha et al., 2013) examined the choice of mode for commuters in Thiruvananthapuram City and found that the significant influencing factors were age, gender, income, vehicle ownership, distance traveled, time per distance, cost per distance. (Salarvandian et al., 2017) researched the city of Tehran, Iran. His research found that transportation mode choice for work trips is influenced by gender, car ownership, income, education, age, number of dependent children, working family, house outside the two traffic zones, and house in OEZ. 


\section{METHODS}

Primary data comes from selected households. The population in this study were all households in Jambi City. The sampling method used was stratified two-stage sampling:

The First Stage, selecting the rukun tetangga ( $R T=$ neighborhood) sample to be the research location. Conducted by purposive sampling with the following considerations and approaches:

1. Jambi City has 11 sub-districts. Of the 11 sub-districts, two were determined with the largest population. Based on the data, it was obtained from Alam Barajo District and Paal Merah District.

2. From each sub-district, one Kelurahan (urban village) with the largest population is determined. Based on this, the Kenali Besar Village in the Alam Barajo District and the Talang Bakung Village in the Paal Merah District were determined.

3. From each selected Kelurahan, three RT are assigned randomly.

The Second Stage, selecting a sample of 25 households in each selected $R T$. The number of selected $R T$ s is $6 R T$, so that the sample size is 150 household samples. Sampling was done by random sampling.

The instrument for collecting data on household samples used a questionnaire. The data were analyzed descriptively to obtain the diversity of transportation modes used in Jambi City. Factors affecting the choice of mode of transportation were analyzed using a logit ordinal regression model:

$$
\begin{gathered}
g\left(x_{k i}\right)=\beta_{0}+\beta_{1} X_{1}+\beta_{2} X_{2}+\beta_{3 D 1} X_{3 D 1}+\beta_{3 D 2} X_{3 D 2}+\beta_{3 D 3} X_{3 D 3}+\beta_{4 D 1} X_{4 D 1}+\beta_{4 D 2} X_{4 D 2} \\
+\beta_{5} X_{5}+\beta_{6} X_{6}+\beta_{7} X_{7}+\beta_{8} X_{8}+\beta_{9} X_{9}+\beta_{10} X_{10}+\beta_{11} X_{11}+e i
\end{gathered}
$$

Information:

$$
\begin{aligned}
& \mathrm{g}(\mathrm{xki})=\text { Transportation Mode } \\
& 1 \text { = Public Vehicle } \\
& 2 \text { = Motorcycle } \\
& 3=\mathrm{Car} \\
& \mathrm{X} 1=\text { Age } \\
& \mathrm{X} 2=\text { Dummy for gender, } 1=\text { Man, } 0=\text { Woman } \\
& \mathrm{X} 3=\text { Formal Education Level (with the basic category of college) } \\
& \text { X3D1 }=1=\text { If Graduated From Elementary School, } 0=\text { Others } \\
& \text { X3D2 }=1=\text { If Graduated From Junior High School, } 0=\text { Others } \\
& \text { X3D3 }=1=\text { If Graduated From Senior High School, } 0=\text { Others } \\
& \text { X4 }=\text { Main Activities (With Basic Categories of Household / Other Affairs) } \\
& \mathrm{X} 4 \mathrm{D} 1=1=\text { If It Works, } 0=\text { Others } \\
& \mathrm{X} 4 \mathrm{D} 2=1=\text { If School, } 0=\text { Others } \\
& \text { X5 }=\text { Number of Household Members } \\
& \mathrm{X} 6=\text { Average (Typical) Daily Trip Traveled Distance } \\
& \mathrm{X} 7=\text { Average Daily Trip Costs (As Usual) } \\
& \mathrm{X} 8=\text { Total Household Income }
\end{aligned}
$$

\section{RESULTS AND DISCUSSIONS}

\section{Characteristics of Jambi City community trips}

Trip characteristics were analyzed based on average daily travel time, average daily travel time, and average daily trip costs. The average daily travel time for the people of Jambi City is 33.93 minutes. Based on the distribution, 45.3 percent traveled more than 
30 minutes, 36.7 percent traveled between 15-30 minutes, and only 18.0 percent traveled less than 15 minutes. This study's findings are almost in line with the research findings (Firdaus \& Gunawan, 2013) in Tanjung Pinang City, where the average travel time is between 20-30 minutes.

Table 1. Distribution of respondents according to the average daily travel time in Jambi City in 2020

\begin{tabular}{lcc}
\hline Travel Time (minutes) & Frequency & \% \\
\hline$<15$ & 27 & 18.0 \\
$15-30$ & 55 & 36.7 \\
$>30$ & 68 & 45.3 \\
\hline Total & 150 & 100.0 \\
\hline Average (minutes) & & 33.93 \\
\hline
\end{tabular}

Furthermore, in terms of daily travel distance, the average is $20.68 \mathrm{Km}$. Based on the distribution, 48.0 percent of the population took daily trips of more than $15 \mathrm{Km}$ per day, followed by distances of $10-15 \mathrm{Km}$ (32.7 percent) and less than $10 \mathrm{Km}(19.3$ percent).

Table 2. Distribution of respondents according to the average daily travel distance in Jambi City in 2020

\begin{tabular}{lcc}
\hline Travel Distance $(\mathbf{K m})$ & Frequency & \% \\
\hline$<10$ & 29 & 19.3 \\
$10-15$ & 49 & 32.7 \\
$>15$ & 72 & 48.0 \\
\hline Total & 150 & 100.0 \\
\hline Average $(\mathrm{km})$ & & 20.68 \\
\hline
\end{tabular}

Based on the Jambi City community's daily travel costs, on average, it is IDR 19,707. By distribution, the largest proportion is in the cost group of $\mathrm{Rp} .10,001-\mathrm{Rp}$. 20,000

Table 3. Distribution of respondents according to average daily travel costs in Jambi City in 2020

\begin{tabular}{|c|c|c|}
\hline Travel Cost (Rp) & Frequency & $\%$ \\
\hline$=<10.000$ & 58 & 38.7 \\
\hline $10.001-20.000$ & 63 & 42.0 \\
\hline$>20.000$ & 29 & 19.3 \\
\hline Total & 150 & 100.0 \\
\hline Average (Rp) & & \\
\hline
\end{tabular}

\section{Jambi City Community transportation mode}

The research findings show that only 22.7 percent of Jambi City people choose public transportation as their daily means of transportation. Most (60.7 percent) use private motorbikes, and 16.7 percent use private cars.

Table 4. Distribution of Respondents by Mode of Daily Travel Transportation in Jambi City in 2020

\begin{tabular}{lcc}
\hline Transportation Modes & Frequency & \% \\
\hline Public Vehicle & 34 & 22.7 \\
Motorcycle & 91 & 60.7 \\
Car & 25 & 16.7 \\
\hline Total & 150 & 100.0 \\
\hline
\end{tabular}


The use of motorbikes as the main choice in this mode of transportation is in line with several other research findings such as those (Firdaus \& Gunawan, 2013) in Tanjung Pinang City (Batti, 2011) in Palu City, (Sari, 2019) in Bogor City. The motorbike's choice is due to its flexibility and travel time, which is faster than public transport causes. Besides, research (Widiarta, 2010) found that the difference between the cost of public transportation and private transportation (especially motorbikes) also triggers the increase in motorbike use.

\section{Factors affecting the choice of community transportation mode in Jambi City}

The Goodness of Fit test using the Deviance method test aims to see whether the ordinal logistic regression model obtained is feasible to use. Deviance represents a measure of how much variation the logistic regression model cannot explain. The higher the deviance value, the less accurate the model will be.

Table 5. The goodness of the fit test model

\begin{tabular}{lccc}
\hline & Chi-Square & df & Sig. \\
\hline Pearson & 236.956 & 269 & .921 \\
Deviance & 173.123 & 269 & 1.000 \\
\hline
\end{tabular}

Link function: Logit.

Based on Table 5, it is known that the Chi-Square value of the Deviance method is 173.123, with a significance value of 1.00 . Because the significance value is greater than $\alpha=0.05$; thus, the conclusion is that the logit model obtained is feasible to use. Furthermore, the model significance test is carried out by comparing the model without the predictor variable (intercept only model) with the predictor (final model). The following shows the results of the model fitting information.

Table 6. Model fitting information

\begin{tabular}{lcccc}
\hline Model & -2 Log Likelihood & Chi-Square & df & Sig. \\
\hline Intercept Only & 281.478 & & & \\
Final & 173.123 & 108.355 & 11 & .000 \\
\hline
\end{tabular}

Link function: Logit.

Based on Table 6, it is known that the -2log Likelihood value of the intercept only model is 281.478, and the $-2 \log$ Likelihood value for the Final model is 173.13. The statistical value of $\mathrm{G}$ (Chi-Square) is 108,355 with a significance of 0,000 . Because the significance value is smaller than $\alpha=0.05$, the decision taken is to reject Ho. Thus, the conclusion is that there is either $\beta p \neq 0$ or a suitable model is a model that contains predictors / independent variables (final model).

Estimated parameters and partial test (Wald test) of the model are given in Table 7. The Wald parameter test results show that of the eight variables proposed in the model, five of them significantly affect the choice of public transportation modes in Jambi City. The variables that significantly affect gender, education, main activities, daily travel costs, and family income. On the other hand, the variables that did not significantly affect age, number of household members, and distance traveled on daily trips.

The significant influence of gender on the choice of transportation mode is in line with several previous studies such as (Toar et al., 2015; Riani et al., 2018; Anderson, 2010; Kamba et al., 2007; Ashalatha et al., 2013; Ashalatha 2013; Salarvandian et al., 2017). Referring to Sari's research results (2019), men find it easier to use public transportation, and women prefer to use private cars and private motorbikes for comfort and safety reasons. 
Table 7. Estimation of model parameters and Wald's Test

\begin{tabular}{|c|c|c|c|c|c|c|}
\hline & & Estimate & $\begin{array}{r}\text { Std. } \\
\text { Error }\end{array}$ & Wald & DF & Sig. \\
\hline Public Vehicle & & 2.033 & 1.158 & 3.080 & 1 & .079 \\
\hline Motorcycle & & 7.191 & 1.345 & 28.601 & 1 & .000 \\
\hline Age & & .033 & .021 & 2.358 & 1 & .125 \\
\hline \multirow[t]{2}{*}{ Gender } & Man & .690 & .408 & 2.854 & 1 & .091 \\
\hline & Woman & $0^{\mathrm{a}}$ & & & 0 & \\
\hline \multirow[t]{4}{*}{ Education } & Elementary School & -1.481 & .806 & 3.376 & 1 & .066 \\
\hline & Junior High School & -1.814 & .776 & 5.468 & 1 & .019 \\
\hline & Senior High School & -1.943 & .626 & 9.626 & 1 & .002 \\
\hline & College & $0^{\mathrm{a}}$ & & & 0 & \\
\hline \multirow[t]{3}{*}{ Main Activity } & Work & 1.254 & .570 & 4.851 & 1 & .028 \\
\hline & School & 3.363 & .830 & 16.426 & 1 & .000 \\
\hline & Others & $0^{\mathrm{a}}$ & & & 0 & \\
\hline Number of household member & & .011 & .138 & .006 & 1 & .936 \\
\hline Distance & & .005 & .015 & .100 & 1 & .752 \\
\hline Daily Cost & & .054 & .020 & 7.157 & 1 & .007 \\
\hline Income & & .436 & .098 & 19.893 & 1 & .000 \\
\hline
\end{tabular}

The influence of education and main activities on transportation modes' choice is also in line with Salarvandian et al.'s (2017) research. In this context, it is argued that public transportation users are much lower than those of private vehicles for work trips.

The daily travel costs affect the choice of mode of transportation. It is in line with the findings of research conducted (Gito Sugiyanto \& Malkhamah, 2009), (Kamba et al., 2007), (Kamba et al., 2007). Furthermore, the influence of family income on the choice of transportation modes is also supported by several previous research findings including (Bella et al., 2013), (Toar et al., 2015) (Wibowo \& Rudiarto, 2017), (Madhuwanthi et al., 2016) ), (Anderson, 2010) (Kamba et al., 2007) (Ashalatha et al., 2013). The reason people choose public transportation as a mode of transportation because of the low income, so they do not have the savings to own a private vehicle.

\section{CONCLUSION AND RECOMMENDATION}

\section{Conclusion}

The main mode of transportation used by the community of Jambi City is private motorbikes. Public transportation is the second choice, and the use of private cars is the third option.

The choice of transportation mode is influenced by gender, main activity, car ownership, motorcycle ownership, and household income. These initial findings will be followed by more in-depth studies related to the phenomenon of choosing this mode of transportation.

\section{Recommendation}

The lack of dominance of community transportation modes' choice is due to the limited and less comfortable public transportation as a means of transportation for Jambi City people. Apart from that, it is also caused by the relatively high cost of public transportation. Therefore, government policy is needed to improve public transportation services and provide subsidies for public transport businesses. 


\section{REFERENCES}

Alfadin, M. R., Hidayat, T., Arifin, M. Z., \& Kusumaningrum, R. (2018). Kajian pemilihan moda antara taksi berbasis aplikasi online dan taksi konvensional kasus kota surabaya. Journal Mahasiswa Teknik Sipil, 1(3), 1-10.

Amin, S., \& Hasbullah, H. (2018). Linking personal attributes, technical skill and managerial competence towards entrepreneurial orientation and the success of traditional home culinary industry. Jurnal Perspektif Pembiayaan Dan Pembangunan Daerah, 5(3), 157-166.

Aminah, S. (2007). Transportasi Publik dan Aksesibilitas Masyarakat Perkotaan. Masyarakat, Kebudayaan Dan Politik, 20(1), 31-45.

Amril, A., \& Junaidi, J. (2019). Do the Economic Losses for Road Users Due To Traffic Congestion: Evidence From Jambi, Indonesia? Innovative Issues and Approaches in Social Sciences, 12(2), 137-153.

Anderson, M. K. A. (2010). Characteristics of trips and travellers in private and public transportation in the danish travel survey data. In Trafikdage på Aalborg Universitet online (Vol. 2010, Issue 2010).

Andriansyah, A. (2015). Manajemen Transportasi dalam Kajian dan Teori. Fakultas Ilmu Sosial dan Ilmu Politik Universitas Prof. Dr. Moestopo Beragama.

Ashalatha, R., Manju, V. S., \& Zacharia, A. B. (2013). Mode choice behavior of commuters in Thiruvananthapuram city. Journal of Transportation Engineering, 139(5), 494-502.

Azis, R., \& Asrul, A. (2018). Pengantar Sistem dan Perencanaan Transportasi. Deepublish.

Batti, J. F. (2011). Studi karakteristik pelaku perjalanan dalam wilayah pelayanan trayek mamboro - manonda di kota palu. Jurnal Rekayasa Dan Manajemen Transportasi, 1(2), 119-128.

Bella, R. ., Malaikosa, K., \& Fanggidae, L. . (2013). Pemodelan Bangkitan Perjalanan Berbasis Rumah Tangga di Kompleks RSS Baumata Kecamatan Taebenu, Kabupaten Kupang. Jurnal Teknik Sipil, 2(1), 63-70.

Böhler-Baedeker, S., Merforth, M., Kost, C., Merforth, M., \& Kumar, K. (2014). Urban Mobility Plans National Approaches and Local Practice. In Sustainable Urban Transport Technical Document \#13. https://itdpdotorg.wpengine.com/wpcontent/uploads/2015/06/TD13_UMP_final.pdf

Bottai, M., Salvati, N., \& Orsini, N. (2006). Multilevel models for analyzing people's daily movement behavior. Journal of Geographical Systems, 8(1), 97-108. https://doi.org/10.1007/s10109-006-0017-x

BPS. (2020a). Jumlah Kendaraan Bermotor Menurut Kabupaten/Kota dan Jenis Kendaraan di Provinsi Jambi (unit), 2019. BPS. https://www.bps.go.id/indikator/indikator/view_data_pub/1500/api_pub/150/da_1 $0 / 1$

BPS. (2020b). Provinsi Jambi dalam Angka 2020. Jambi: BPS.

Cao, X., Mokhtarian, P. L., \& Handy, S. L. (2007). Cross-sectional and quasi-panel explorations of the connection between the built environment and auto ownership. Environment and Planning A, 39(4), 830-847. https://doi.org/10.1068/a37437

Dwiatmoko, H. (2019). Peran Infrastruktur Perkeretaapian bagi Pertumbuhan Ekonomi Wilayah. Jurnal Manajemen Aset Infrastruktur \& Fasilitas, 3(2), 89-98. https://doi.org/10.12962/j26151847.v3i2.5883 
Firdaus, O., \& Gunawan, I. (2013). Analisis Pola Perjalanan Orang Di Kota Pangkal Pinang. Jurnal Fropil, 1(2), 134-149.

Handy, S., Cao, X., \& Mokhtarian, P. L. (2006). Self-selection in the relationship between the built environment and walking: Empirical evidence from Northern California. Journal of the American Planning Association, 72(1), 55-74. https://doi.org/10.1080/01944360608976724

Indra, S., \& Sukarman, S. (2014). Model Pemilihan Moda Angkutan Pribadi dan Angkutan Umum pada Daerah Rute Transmusi Korior IV. Jurnal Teknik Sipil, 10(2), 132-139.

Kamba, A. N., Rahmat, R. A. O. K., \& Ismail, A. (2007). Why Do People Use Their Cars: A Case Study In Malaysia. Journal of Social Sciences, 3(3), 117-122. https://doi.org/10.3844/jssp.2007.117.122

Limtanakool, N., Dijst, M., \& Schwanen, T. (2006). The influence of socio-economic characteristics, land use and travel time considerations on mode choice for mediumand longer-distance trips. Journal of Transport Geography, 14(5), 327-341. https://doi.org/10.1016/j.jtrangeo.2005.06.004

Madhuwanthi, R. A. M., Marasinghe, A., Rajapakse, R. P. C. J., Dharmawansa, A. D., \& Nomura, S. (2016). Factors Influencing to Travel Behavior on Transport Mode Choice. International Journal of Affective Engineering, 15(2), 63-72. https://doi.org/10.5057/ijae.ijae-d-15-00044

Maryanta, M. (2005). Keputusan Penumpang dalam Memililh Jenis Angkutan Umum Bus untuk Tujuan Perjalanan ke Tempat Kerja di Kotamadya Jakarta Barat: Analisis Multinomial Logit [Institut Pertanian Bogor]. https://repository.ipb.ac.id/handle/123456789/9359

Rahmani, U. (2000). Analisis Perkembangan Transportasi dan Sistem Interaksi Spasial di Kota Bogor. Institut Pertanian Bogor.

Riani, D., Amin, M., \& Hidayat, I. F. (2018). Model Pemilihan Moda Perjalanan Menuju Pusat Perbelanjaan Menggunakan Kendaraan Pribadi (Sepeda Motor dan Mobil). Jurnal Teknika, 1(2), 105-113.

Salarvandian, F., Dijst, M., \& Helbich, M. (2017). Impact of traffic zones on mobility behavior in Tehran, Iran. Journal of Transport and Land Use, 10(1). https://doi.org/10.5198/jtlu.2017.1087

Salim, A. (2016). Manajemen Transportasi. PT Raja Grafindo Persada.

Sari, H. P. (2019). Analisis Pilihan Moda Transportasi Masyarakat di Kota Bogor. Institut Pertanian Bogor.

Sekhar, C. R. (2014). Mode Choice Analysis: the Data, the Models and Future Ahead. International Journal for Traffic and Transport Engineering, 4(3), 269-285. https://doi.org/10.7708/ijtte.2014.4(3).03

Setyodhono, S. (2017). Faktor yang Mempengaruhi Pekerja Komuter di Jabodetabek Menggunakan Moda Transportasi Utama. Warta Penelitian Perhubungan, 29(1), 21. https://doi.org/10.25104/warlit.v29i1.326

Sugiyanto, G. (2013). Model Pemilihan Moda dan Perbandingan Perilaku Perjalanan: Studi Kasus di Yogyakarta dan Filipina). Konferensi Nasional Teknik Sipil 7.

Sugiyanto, Gito, \& Malkhamah, S. (2009). Pemilihan Moda Antara Mobil Pribadi Dan Bis Transjogja. Jurnal Transportasi, 9(2), 97-106.

Tamin, O. Z. (2000). Perencanaan dan Pemodelan Transportasi. Bandung: Penerbit ITB. Toar, J. I., Timboeleng, J. A., \& Sendow, T. K. (2015). Analisa Pemilihan Moda Angkutan Kota Manado - Kota Gorontalo Menggunakan Model Binomial-Logit- 
Selisih. Jurnal Sipil Statik, 3(1), 27-37.

Wibowo, W., \& Rudiarto, I. (2017). Pengaruh Karakteristik Penumpang Pesawat Terhadap Peluang Pemilihan Moda Menuju Bandara Baru Kulonprogo. Jurnal Pembangunan Wilayah \& https://doi.org/10.14710/pwk.v13i4.18269

Widiarta, I. P. (2010). Analisis Pemilihan Moda Transportasi Untuk Perjalanan Kerja. Jurnal Ilmiah Teknik Sipil, 14(2), 218-225. 